\title{
MEDIA KOMIK DALAM MENINGKATKAN KETERAMPILAN MEMBACA SISWA DI GUBUK BACA SEKOLAH PAGESANGAN WINTAOS GUNUNGKIDUL (Studi Fenomenologi)
}

\author{
Nurasiah Hasanah \\ Universitas Islam Negeri Sunan Kalijaga Yogyakarta \\ nurasiah4247@gmail.com
}

\begin{abstract}
This study aims to describe the media of comics in improving reading skills of Pagesangan School students. The method used in this research is qualitative-phenomenological method. Data collection uses unstructured interviews and direct observation with the subjects of two participants. The results of interviews with participants obtained information about various feelings, perceptions, experiences and knowledge about comic media in improving reading skills, comic media is very influential in improving reading skills because the pictures are interesting and easily understood by students. The results of the study are expected to be a reference for teaching materials for formal and non-formal schools.
\end{abstract}

Keywords: comic media, reading skills

Abstrak: Penelitian ini bertujuan untuk mendeskripsikan media komik dalam meningkatkan keterampilan membaca siswa Sekolah Pagesangan. Metode yang digunakan dalam penelitian ini adalah metode kualitatif-fenomenologis. Pengumpulan data menggunakan wawancara tidak terstruktur dan observasi secara langsung dengan subjek dua partisipan. Hasil wawancara pada partisipan didapatkan informasi tentang berbagai perasaan, persepsi, pengalaman dan pengetahuan tentang media komik dalam meningkatkan keterampilan membaca, media komik sangat berpengaruh dalam meningkatkan keterampilan membaca karena gambar yang menarik dan mudah dipahami oleh siswa. Hasil penelitian diharapkan bisa menjadi acuan untuk bahan ajar bagi sekolah formal maupun non formal.

Kata Kunci: media komik, keterampilan membaca

Pendidikan merupakan salah satu faktor terpenting dalam meningkatkan sumber daya manusia dan taraf kehidupan bangsa. seperti tercantum dalam tujuan Pendidikan Nasional Nomor 20 Tahun 2003 pasal 3 yang berbunyi:

"Pendidikan nasional berfungsi mengembangkan kemampuan dan membentuk watak serta peradaban bangsa yang bermartabat dalam rangka mencerdaskan kehidupan bangsa, bertujuan untuk berkembangnya potensi peserta didik agar menjadi manusia yang beriman dan bertaqwa terhadap 
Tuhan Yang Maha Esa, berakhlak mulia, sehat, berilmu, cakap, kreatif, mandiri dan menjadi warga negara yang demokratis serta bertanggungjawab".

Semakin baik pendidikan di suatu bangsa, maka semakin baik pula kualitas bangsa itu, itulah asumsi secara umum terhadap program pendidikan suatu bangsa. Secara faktual pendidikan menggambarkan kegiatan sekelompok orang atau anggota kelompok seperti kepala sekolah, guru, dan siswa, yang di dalamnya terjadi interaksi dalam melaksanakan pendidikan dan bekerjasama dengan orang-orang berkepentingan. Secara perspektif, pendidikan ialah arahan, muatan, dan pilihan yang tepat sebagai wahana pengembangan masa depan peserta didik yang tidak terlepas dari kontrol manusia sebagai pendidik.

Salah satu wadah pendidikan adalah sekolah, baik sekolah yang berada di bawah naungan pemerintah ataupun dibawah naungan masyarakat umum, baik yang formal maupun non formal. Seperti salah satu sekolah yang didirikan oleh para pegiat yang peduli lingkungan, yaitu Sekolah Pagesangan. Sekolah Pagesangan adalah sekolah yang didirikan oleh pegiat-pegiat lingkungan untuk memberdayakan masyarakat dan anak-anak supaya lebih produktif, baik dalam hal pemberdayaan hasil alamnya ataupun kemampuan akademis, minat bakat siswa-siswa dan pemahaman agamanya. Sekolah Pagesangan berada di Gunung Kidul, tepatnya di Wintaos, Girimulyo, Kec. Panggang. Sekolah Pagesangan ini didirikan dengan latar belakang kurangnya pemberdayaan masyarakat terhadap hasil alam yang ada, dan rendahnya pendidikan masyarakat Wintaos terutama dalam hal membaca dan pemahaman pada pendidikan agama, yang mayoritas masyarakatnya beragama islam, banyak anak putus sekolah dan masyarakat yang buta huruf sehingga tidak bisa membaca buku maupun Al-Qur'an.

Menurut Harjasujana dan Mulyati, minat membaca berbanding lurus dengan tingkat kemajuan pendidikan suatu bangsa. Kegiatan membaca merupakan hal yang sangat penting bagi kemajuan suatu bangsa dan agama. Parameter kualitas suatu bangsa dapat dilihat dari kondisi pendidikannya. Pendidikan selalu berkaitan dengan kegiatan belajar. Dalam memahami pendidikan di sini, maka 
pendidikan menjadi sangat penting untuk meningkatkan minat baca siswa baik di Sekolah ataupun diluar Sekolah atau dalam agama sekalipun.

Berdasarkan studi "The World's Most Literate Nations (WMLN)" yang dilakukan oleh John W. Miller, presiden Central Connecticut State University, pada Maret 2016, Indonesia dinyatakan menduduki peringkat ke-60 dari 61 negara tentang minat membaca. Di beberapa berita disebutkan, minat baca orang Indonesia persis berada di bawah Thailand dengan peringkat 59 dan di atas Bostwana dengan peringkat 61. Lebih lanjut, PISA juga menyebutkan tidak ada satupun siswa di Indonesia yang meraih nilai literasi atau kemampuan mengolah informasi saat membaca dan menulis di tingkat kelima, hanya $0,4 \%$ siswa yang memiliki kemampuan literasi tingkat empat. Sedangkan yang lain di peringkat ketiga, bahkan di bawah tingkat satu. Rendahnya minat membaca di Indonesia, membuat siswa-siswa tidak melek aksara. Padahal membaca merupakan jendela dunia, dengan membaca akan menambah wawasan.

Hampir semua aspek dalam kehidupan melibatkan kegiatan membaca, sehingga peran membaca sangat penting bagi kehidupan manusia. Burn dkk. (Rahim, 2008, hlm. 6). Membaca merupakan jendela dunia, dalam agama membaca Al-Qur'an merupakan salah satu cara berkomunikasi dengan TuhanNya, dengan membaca semua orang dapat mengelilingi dunia secara gratis, beribadah dan berkomunikasi dengan baik pada Tuhan. Namun tidak banyak orang yang mempunyai kebiasaan membaca yang teratur. Tingkat minat mebaca di Indonesia pun sangat rendah. Termasuk di sekolah-sekolah, tingkat baca masih sangatlah rendah apalagi di kalangan masyarakat. Dibutuhkan strategi khusus untuk menumbuhkan minat baca baik di sekolah di masyarakat terutama dalam beribadah, supaya siswa bisa lebih terampil dalam membaca dan memaknai isi bacaan. Dalam menyikapi keprihatinan ini, maka ditetapkannya Gerakan Literasi Sekolah, seperti yang tercantum dalam Peraturan Menteri Pendidikan dan Kebudayaan nomor 23 tahun 2015. Dalam peraturan ini Gerakan Literasi Sekolah dilaksanakan supaya siswa dapat menumbuhkan budi pekerti luhur.

Dari hal inilah para pegiat literasi mendirikan Sekolah Pagesangan, kemudian mereka juga mendirikan taman baca dengan nama GUBA atau Gubuk 
Baca yang di dalamnya juga memuat pelajaran agama, para pegiat sangat peduli akan melek aksara dan sadar ibadah, karena tercatat di gunung Kidul minat membaca masih sangatlah rendah. Masih banyak siswa putus Sekolah. Sehingga para pegiat ini berinisiatif menyediakan banyak buku bacaan yang menarik untuk di baca oleh anak-anak di luar jam sekolah atau di hari libur, sekolah ini biasanya dilaksanakaan pada hari sabtu dan minggu supaya waktu anak-anak tidak terbuang sia-sia, selain itu adanya GUBA juga untuk meningkatkan semangat mereka membaca. Selain itu membaca juga merupakan seruan pertama yang diperintahkan Tuhan kepada Nabi Muhammad melalui malaikat Jibril. Sesuai dengan penjabaran Literasi sekolah dalam konteks Gerakan Literasi Sekolah, yaitu kemampuan mengakses, memahami, dan menggunakan sesuatu secara cerdas melalui berbagai kegiatan ataupun aktivitas, antara lain membaca, melihat, menyimak, menulis dan atau berbicara (Sutrianto dkk, 2016: 2). Dalam hal ini literasi yang dimaksud adalah kemampuan siswa dalam mengakses, memahami, dan menggunakan sesuatu secara cerdas melalui berbagai kegiatan terutama dalam hal membaca dan berbicara serta bisa bernilai ibadah.

Membaca adalah salah satu dari empat keterampilan berbahasa. Membaca adalah suatu proses yang dilakukan serta dipergunakan oleh pembaca untuk memperoleh pesan, yang hendak disampaikan oleh penulis melalui media katakata/bahasa tulis. Suatu proses yang menuntut agar kelompok kata yang merupakan suatu kesatuan akan terlihat dalam suatu pandangan sekilas dan makna kata-kata secara individual akan dapat diketahui. Kalau hal ini tidak terpenuhi, pesan yang tersurat dan tersirat yang tidak akan tertangkap atau dipahami, dan proses membaca itu tidak terlaksna dengan baik (Hodgson dalam Henry Guntur Tarigan, 2008: 7). Selain menumbuhkan minat membaca, siswa juga harus memiliki keterampilan membaca supaya bisa memehami isi bacaan dengan baik dan benar.

Keterampilan membaca merupakan salah satu aspek keterampilan berbahasa yang terdapat dalam kurikulum pembelajaran. Keterampilan membaca selalu ada dalam setiap tema pembelajaran dan dapat diterapkan dalam membaca Al-Qur'an. Menurut Nurhadi (1995:340). Membaca interpretatif adalah kegiatan 
membaca yang bertujuan agar siswa mampu menginterpretasikan atau menafsirkan yang dimaksud oleh pengarang atau penulis. Apakah karangan itu fakta atau fiksi, sifat-sifat tokoh, reaksi emosional, gaya bahasa dan bahasa kias, serta dampak-dampak cerita tersebut terhadap pembacanya. Dalam membaca interpretatif pembaca dituntut memahami makna yang tersirat dari bacaan (Dalman, 2014: 87). Keterampilan membaca juga merupakan bagian dari pengembangan membaca, tujuan dari keterampilan membaca ada banyak. Tujuannya adalah memahami isi bacaan, menyimpulkan isi bacaan, dan menangkap apa yang dimaksud dalam bacaan atau buku tersebut termasuk dalam kitab suci Al-Qur'an.

Keterampilan membaca bisa diperoleh dari mana saja, keterampilan membaca pada umumnya diperoleh dengan cara mempelajarinya di sekolah bisa juga dalam pelajaran agama. Keterampilan membaca ini merupakan suatu keterampilan yang sangat unik serta berperan penting bagi pengembangan pengetahuan, dan sebagai alat komunikasi bagi kehidupan manusia, dikatakan unik karena tidak semua manusia, walaupun telah memiliki keterampilan membaca, dapat mengembangkannya menjadi alat untuk memberdayakan dirinya atau bahkan menjadikannya budaya bagi dirinya sendiri, dikatakan penting bagi pengembangan pengetahuan karena persentase transfer ilmu pengetahuan terbanyak dilakukan melalui membaca (Iskandarwassid \& Sunendar, 2011)

Melihat fenomena sekarang, pemahaman siswa terhadap isi bacaan masih rendah terutama pada pelajaran agama, dibutuhkan metode atau media lain untuk memudahkan siswa menangkap isi bacaan dari buku yang mereka baca. Fenomena diatas seperti halnya yang dialami oleh Sekolah Pagesangan pada awal dibuka, sebelum adanya Guba dan belum berjalan lama Sekolah Pagesangan juga hanya menyediakan buku-buku bacaan yang hanya tekstual dan membuat para siswanya jenuh dan tidak menarik perhatian siswa untuk membaca bahkan tentang pemahaman Islam, sehingga banyak siswa yang berhenti dan tidak mengikuti Sekolah Pagesangan lagi.

Setelah sekian lama banyak siswa yang kabur karena metode Sekolah Pagesangan sama dengan Sekolah formal termasuk buku bacaan dan buku ajar 
agama yang tekstual yang membuat siswa jenuh, akhirnya para pegiat Sekolah Pagesangan membuat inovasi baru yaitu menyediakan buku-buku bergambar atau biasa kita ketahui sebagai komik untuk menarik minat siswa datang kembali ke Sekolah Pagesangan dan mempermudah mereka dalam memahami isi buku tersebut sehingga mereka tidak merasa jenuh dan senang membaca, terutama cerita-cerita yang menceritakan tentang kisah-kisah nabi sehingga memudahkan mereka memahami dan senang belajar agama. Menurut (Hurlock, 1997) untuk mendukung keterampilan membaca ada banyak metode atau cara salah satunya adalah penyajian buku bergambar atau komik. Manfaat dari komik antara lain: 1) komik membekali siswa dengan kemampuan membaca yang terbatas melalui pengalaman membaca yang menyenangkan, 2) komik dapat digunakan untuk memotivasi siswa mengembangkan ketrampilan membaca, 3) komik memberi siswa sumber katarsis emosional bagi emosi yang tertahan, 4) siswa mungkin mengidentifikasi dirinya dengan tokoh buku komik yang memiliki sifat yang dikaguminya, 5) siswa memperoleh kesempatan yang baik untuk mendapat wawasan mengenai masalah pribadi dan sosialnya, 6) mudah dibaca, bahkan siswa yang kurang mampu membaca dapat memahami arti dari gambarnya, 7) menarik imajinasi siswa dan rasa ingin tahu tentang masalah supranatural.

Komik dapat didefinisikan sebagai suatu bentuk kartun yang mengungkapkan karakter yang memerankan suatu cerita dalam urutan yang erat dihubungkan dengan gambar yang dibukukan dan dirancang untuk memberikan hiburan kepada pembacanya ( Sudjana dan Rivai 2002: 64). Kesenangan siswasiswa terhadap komik dapat dimanfaatkan sebagai indikator pemilihan objek pengembangan keterampilan membaca. Komik yang jauh dari kesan edukatif dapat diubah menjadi lebih edukatif dan bermanfaat untuk meningkatkan keterampilan membaca. Komik juga akan membuat siswa menjadi senang belajar, terutama mengenai agama, memudahkan mereka memahaminya. Karena pada dasarnya mereka memang menyukai komik. Oleh karena itu, tepat rasanya melakukan penelitian terhadap komik yang menjadi media dalam upaya meningkatkan keterampilan membaca siswa. 
Melihat fenomena sekarang, masih banyak siswa yang kurang dalam memahami bacaan atau buku karena terlalu tekstual. Dengan penerapan media bacaan bergambar atau komik yang dilakukan oleh GUBA ternyata dapat meningkatkan minat membaca dan keterampilan membaca siswa. Maka dari itu penulis tertarik untuk meneliti bagaiamana fenomena media komik dalam meningkatkan keterampilan membaca siswa di Sekolah Pagesangan.

\section{HASIL}

Berdasarkan hasil wawancara dengan salah satu siswa yang kini sudah menjadi relawan ajar di Sekolah Pagesangan yang bernama Nur Livia (17), dahulu beliau adalah murid dari Sekolah Pagesangan kemudian sekarang mengabdi menjadi relawan untuk membantu siswa-siswa SD belajar di Sekolah Pagesangan. Pada mulanya Sekolah Pagesangan ini bernama Sekolah Panguripan didirikan pada tahun 2008, dahulu Sekolah inididirikan oleh relawan-relawan salah satu namanya adalah "Mbak Diah", Sekolah ini dahulunya dibuat seperti les ada bahasa inggris, matematika, IPA, dan ada pelajaran agama, selain itu juga diajarkan membuat pupuk, makanan-makanan dan dijadikan perlombaan untuk memotivasi kami terus belajar di sana. Tetapi karena ada konflik antar relawan akhirnya bubar. Pada tahun 2013 Mbak Diah mendirikan kembali Sekolah, yang namanya Sekolah Pagesangan yang diberi nama oleh Mbah Siswoharjono (sesepuh kampung), Mbak Diah adalah relawan paling peduli dan yang masih bertahan diantara relawan-relawan lainnya Sekolah Pagesangan memiliki arti Sekolah Kehidupan yang memiliki harapan siswa-siswa yang belajar disini bisa menghidupkan kampung, dirinya sendiri dan agamanya. Awalnya Sekolah Pagesangan ini mengikuti metode lama, yaitu mengajari siswa-siswa mata pelajaran seperti biasanya seperti di sekolah-sekolah biasa, hanya saja kurang menarik minat siswa untuk datang karena menjenuhkan. Sampai pada akhirnya, Mbak Diah berinisiatif untuk lebih mengembangkan kepada hasil alam di daerah tersebut, karena mayoritas masyarakat kami disana adalah petani, maka siswasiswa mulai diajari bercocok tanam, membuat kompos, sampai ke mengolah hasil alamnya juga. Sekolah Pagesangan juga memiliki lahan sendiri untuk siswa terjun 
langsung menanam, panen, kemudian produksi sampai dijual. Sehingga menarik minat siswa untuk ikut gabung di Sekolah Pagesangan.

Seiring berjalannya waktu, semakin bertambah relawan-relawan ajar Sekolah Pagesangan, banyak pegiat-pegiat literasi juga ikut bergabung karena melihat minat membaca siswa sangat rendah, pengetahuan agama yang sangat minim dan banyak yang ketergantungan pada gadget, sehingga banyak waktu yang terbuang sia-sia dan tidak berguna. Dari sini Mbak Diah pun berkolaborasi dengan relawan-relawan ajar pegiat literasi dengan membuat Gubuk Baca yang berbasis agama (Guba) pada tahun 2016, untuk memfasilitasi siswa belajar dan membaca dengan bahan bacaan hasil donasi daripara donatur, karena sebelumnya Sekolah Pagesangan tidak memiliki tempat belajar secara tetap sehingga siswa belajar berpindah-pindah tempat dari satu rumah ke rumah lainnya. Tetapi setelah adanya Guba, akhirnya siswa-siswa mempunyai tempat sendiri untuk belajar, mempelajari agama dan membaca selain di TPA (tempat pengajian anak). Awalnya Guba ini ramai tetapi semakin hari semakin berkurang siswanya, akhirnya diadakan evaluasi dan siswa ditanya kenapa jarang datang ke sekolah lagi, mereka pun menjawab, "buku-bukunya membuat pusing, susah dipahami”, karena pada awalnya bacaan-bacaan yang disediakan memang bacaan yang kebanyakan tekstual, apalagi permasalahan agama sehingga tidak menarik bagi siswa-siswa, membuat siswa sulit memahami bacaan tersebut. Siswa-siswa yang biasa datang pun mulai jenuh hingga pada akhirnya berkurang sedikit demi sedikit. Tetapi para relawan ajar mencari inisiatif baru dan karena mereka sudah memiliki banyak kenalan donatur buku, akhirnya mereka menghadirkan bukubuku komik yang menarik untuk menarik minat baca siswa. Awalnya supaya siswa kembali sekolah di Sekolah Pagesangan, siswa diajak lomba memasak, membaca dan menyampaikan isi bacaan dengan berbagai hadiah menarik seperti buku dan alat-alat tulis supaya siswa datang kembali ke gubuk baca, dan setelah lomba selesai mereka malah berbondong-bondong bahkan antri untuk meminjam buku, hal ini dapat dilihat dari kartu peminjaman buku yang makin hari makin penuh saja. Setiap Sabtu dan Minggu siswa-siswa datang ke Gubuk baca untuk meminjam buku dan membacanya. 
Antusiasme siswa-siswa dalam membaca melebihi ekspektasi para relawan, sistem yang digunakan di gubuk baca adalah 3M, meminjam, membaca dan menceritakan kembali. Biasanya siswa-siswa harus ditunjuk terlebih dahulu untuk menceritakan apa yang mereka baca, dan biasanya mereka tidak mau menceritakan karena tidak paham apa yang mereka baca karena terlalu tekstual dan kata siswa-siswa bacaannya bikin pusing. Tetapi setelah disediakan buku bacaan komik, siswa-siswa berlomba-lomba meminjam, bahkan sebelum diminta untuk menceritakan isi bacaan pun, mereka berani maju dan menceritakan apa yang mereka baca. Komik-komik yang disediakan, berupa komik edukatif, seperti komik religius yang menceritakan nabi-nabi bahkan siswa bisa belajar story telling juga dari adanya komik sejarah-sejarah nabi ini. Kemudian ada komikkomik binatang, tumbuhan dan hitung-hitungan pun ada sehingga memudahkan siswa untuk memahaminya.

Namun dari keberhasilan tersebut tidak terlepas dari berbagai masalah yang datang menghampiri Sekolah Pagesangan, sesuai dengan penuturan Livia:

“meskipun hasil yang dilihat dari luar bagus, tetapi kami pun melewati ini semua dengan berbagai rintangan dan masalah mbak, mulai dari bedanya pemikiran antara pengajar, adanya perselisihan, sampai sekolah ini mau bubar lagi karna relawan-relawan selisih paham. Saya juga pernah sampai malas untuk mengajar lagi,karena ada perselisihan sama pengajar yang klain, tetapi ya saya kuat-kuatin demi anak-anak dan majunya sekolah".

Dalam mencapai suatu keberhasilan pasti selalu ada masalah yang harus dihadapi, selain masalah yang bersumber dari luar ada juga masalah yang bersumber dari diri itu sendiri, seperti yang dialami Livia saat menjadi siswa dan menjadi relawan mengajar di Sekolah pagesangan,

“meskipun saya bisa menemukan jati diri dan menjadi diri saya sendiri di sekolah ini, tapi ya saya juga manusia mbak, kadang jenuh dan malas harus belajar mulu, buku-buku itu aja, anak-anak yang kadang bikin jengkel, hehe, tapi ya balik lagi ke niat sih, niat belajar dan mengabdi untuk masyarakat serta bagian dariibadah kepada Allah SWT. Jadi 
alhamdulillah disyukuri saja ada buku-buku bantuan aja alhamdulillah, anak-anak mau sekolah juga udah kebahagian, ya cuman kalau mood lagi jelek aja kadang ngedumel."

Selain dua faktor eksternal dan internal tersebut ada juga yang menghambat proses belajar mengajar dan keberhasilan belajar di Guba, yaitu adanya komik dan bacaan berbahasa inggris, hal inilah yang menjadi penghambat, belum adanya relawan yang mahir berbahasa Inggris dan karena siswa-siswa belum terlalu paham bahasa Inggris, jadi mereka tidak bisa membacanya. Tetapi secara keseluruhan, melihat perkembangan dalam kurun waktu selama kurang lebih 2,5 tahun minat baca dan keterampilan membaca siswa sangat meningkat pesat dan pemahaman agamanya juga meningkat, mereka jadi rajin membaca AlQur'an dan setiap sebelum pelajaran dimulai dibiasakan membaca Al-Qur'an juga. Dari keseluruhan adanya sekolah pagesangan dan gubuk baca ini ditambah dengan adanya buku-buku bergambar dan komik yang menarik siswa, sangat membantu dan memajukan perkembangan siswa terutama dalam hal membaca dan agama.

"saya sendiri merasa senang dengan adanya Sekolah Pagesangan ini, apalagi saya generasi pertama dari Sekolah ini, dulu mau berbicara didepan kelas saja mana berani mbak tapi sekarang malah sudah bisa ikutan ngajar juga, paham agama juga enggak mbak, sekarang malah bisa ngajarin anak-anak ngaji belajar story telling menceritakan kisah-kisah nabi, ya meskipun pas saya SD ajarannya masih bacaan-bacaan tulisan doang nggak ada gambarnya, hehe”

Peran dari adanya media komik yang disediakan Guba di Sekolah Pagesangan sangat membantu dalam perkembangan keterampilan membaca siswa baik dalam hal pelajaran, agama, maupun kepercayaan diri. Selain mewawancarai Livia yang pernah menjadi siswa dan sekarang menjadi relawan ajar, peneliti juga mewawancarai siswa yang masih aktif di Sekolah Pagesangan, Kharisma (11 tahun) siswa kelas 5. Dia adalah salah satu siswa yang aktif di Sekolah Pagesangan. Menurut pengalaman dia sekolah di sana, dia merasa senang, karena sekolah di sana bisa sambil bermain juga, 
"sekolahnya asik, pelajarannya gak bikin pusing dan bukunya asik-asik banyak gambarnya gitu mbak",

Sekolah yang tidak monoton, tidak hanya terfokus ke pelajaran saja, menciptakan inovasi-inovasi baru dengan menghargai alam, mengajarkan mengolah hasil alam, mengajarkan belajar tanpa paksaan, memfasilitasi bacaanbacaan menarik, menyediakan media komik, belajar agama dengan asik, mengajarkan siswa memahami bacaan dan menceritakan isi bacaan sebagai upaya pengembangan keterampilan membaca dan membuat siswa percaya diri berbicara di depan khalayak umum.

Pengolahan alam dan media komik disini menjadi daya tarik tersendiri untuk para siswa, seperti yang diceritakan oleh kharisma pengalamannya sekolah di Sekolah Pagesangan,

"sekolah neng kene ki penak lho mbak, gratis hehe, iso dolan, gek sinau eh belajar bercocok tanam, terus nanti panen kalau udah pada mateng terus di masak hasilnya, kaya kacang ijo,kita pernah bikin bubur kacang ijo dari tanaman yang kita tanam lho"

Di sekolah pagesangan, selain ditanamkan budaya membaca, siswa juga dilatih skill memberdayakan hasil bumi yang ada di kampung Wintaos sebagai bukti syukur pada Allah SWT.

"belajar disini juga enak mbak, gak kaya disekolah biasanya, ibunya galak (berbisik), disini buku-bukunya juga apik (bagus) banyak gambargambarnya, aku kalo habis baca bisa langsung cerita ke mbak livia atau ke mbak ela (relawan ajar) dari yang aku baca, kadang kan disuruh juga, tapi karna bukunya enak banyak gambarnya gampang tau isi ceritanya, jadi aku gak nunggu disuruh biar dikasih bintang banyak sama mbak liv, hehe".

\section{PEMBAHASAN}

Berdasarkan pengalaman yang diceritakan oleh Livia dan Kharisma bahwa Sekolah Pagesangan sangat menarik, karena sekolah ini bukan hanya mengajarkan pembelajaran formal, melainkan mengajarkan nilai-nilai kehidupan serta agama. 
Selain itu dengan adanya Guba yang menyediakan media komik dalam mengembangkan keterampilan membaca, banyak membawa dampak baik terhadap siswa, selain memudahkan siswa membaca, siswa juga jadi percaya diri dalam berbicara di depan teman-temannya ataupun di depan kelas ketika sekolah. Selain banyak hal yang menyenangkan dan membantu dalam perkembangan di Sekolah Pagesangan, ternyata ada hal-hal yang menghambat perkembangan dan kemajuan sekolah ini bagi siswa. Ada banyak faktor diantaranya adalah faktor dari eksternal dan internal

Menurut penuturan kharisma, dari membaca dia banyak mendapatkan ilmu yang sangat bermanfaat, banyak bersyukur pada Allah SWT, pandai mengaji dan lebih menghormati orangtua. Namun tetap saja seiring berjalannya waktu kadang membaca juga membosankan, dan membuat dia malas, meskipun ada berbagai macam bacaan yang menarik dan banyak gambarnya. Selain itu di usia Kharisma yang masih muda dan masih labil, kadang ada pertengkaran sesama temannya yang membuat dia malas datang ke sekolah dan kebiasaan membacanya terganggu. Sehingga saat akan memulai membiasakan membaca lagi, membuat dia malas. Tetapi meskipun begitu, berdasarkan penuturan kharisma dan Livia, kharisma tetap aktif di sekolah pagesangan sampai sekarang, pinjaman bukunya pun makin hari makin bertambah, pemahamn dia terhadap bacaan dan agama semakin meningkat, terlihat dari cara dia menyampaikan isi cerita dari komik yang dia baca dan bacaan Al-Qur'an yang semakin fasih.

\section{SIMPULAN}

Dari pengalaman kedua subjek dapat disimpulkan bahwa dalam meningkatkan keterampilan membaca, buku bacaan juga sangat mempengerahi untuk berkembangnya keterampilan membaca siswa. Buku-buku bacaan tekstual kurang efektif untuk menarik dan membiasakan siswa membaca, apalagi merefleksikan apa yang mereka baca. Adanya media komik-komik edukatif yang disediakan Gubuk Baca Sekolah pagesangan sangat mempengaruhi terhadap berkembangnya keterampilan membaca siswa. 
Media komik sudah berhasil meningkatkan keterampilan membaca siswa, mulai dari menarik minat membaca, membiasakan siswa membaca dan siswa pun bisa menceritakan kembali apa yang mereka baca. tetapi selain itu ada beberapa faktor yang menghambat perkembangan keterampilan membaca siswa diantaranya faktor eksternal dan internal. Faktor eksternal yang menghambat keterampilan membaca siswa adalah adanya kejenuhan siswa terhadap buku bacaan, meskipun buku bacaan sudah dimodifikasi dengan adanya buku-buku komik. Adanya perselisihan dengan teman dan tidak enaknya relawan yang mengajar juga menjadi faktor penghambat. Selain itu ada juga faktor internal yang menjadi penghambat, yaitu adanya rasa malas dan bosanyang timbul dari diri sendiri. 


\section{DAFTAR PUSTAKA}

Ahmad Fajar Tabroni, 13144600105. "PENGEMBANGAN MEDIA KOMIK PADA PEMBELAJARAN KETERAMPILAN MEMBACA PEMAHAMAN UNTUK SISWA KELAS IV SD NEGERI GROJOGAN TAMANAN BANTUL.” Prodi PGSD Universitas PGRI Yogyakarta (2017). Accessed March 11, 2019. http://repository.upy.ac.id/1576/.

A.S. Harjasujana dan Mulyati, 1997. Membaca Dalam Teori Dan Praktik. Bandung: Mutiara.

Dinno Baskoro, "Minat Baca Masih Rendah, Indonesia Peringkat Ke-60 Dari 61 Negara Yang Disurvei Central Connecticut State University!: Okezone Lifestyle," Lifestyle, Oktober 2017,https://ifestyle.okezone.com/read/2017/10/05/196/1789397/minatba

ca- masih rendah indonesia peringkat-ke-60-dari-61-negara-yang-disurvei centralconnecticut- state-university

Dalman.2014. Keterampilan Membaca. Jakarta: Raja Grafindo Persada..

Eruin Indaryanta, "Implementasi Program Gerakan Literasi Sekolah Di SD Kristen Kalam Kudus Dan SD Muhammadiyah Suronatan," Jurnal Kebijakan Pendidikan VI (2017): 733.

Hurlock,E.B. 1997. Perkembangan anak. Jilid 1. Med Meitasari (penterjemah). Jakarta: Penerbit Erlangga.

Moh. Kasiram, 2003. Metodologi Penelitian Kualitatif-Kuantitatif. Malang: UIN MALIKI PRESS.

Undang-undang No 20 Tahun 2003 tentang Sistem Pendidikan Nasional

Poerwandari, E.K. 2005. Pendekatan kualitatif dalam penelitian psikologi. Jakarta: LPSP3 UI

Sutrianto, dkk. 2016. Panduan Gerakan Literasi Sekolah di Sekolah Menengah Atas. Jakarta: Direktorat jendral pendidikan dasar dan menengah kementrian pendidikan dan kebudayaan. 